\title{
Stage II Gallbladder Cancer AJCC v7
}

National Cancer Institute

\section{Source}

National Cancer Institute. Stage I/ Gallbladder Cancer A/CC v7. NCI Thesaurus. Code C90217.

Stage II includes: T2, N0, M0. T2: Tumor invades perimuscular connective tissue; no extension beyond serosa or into liver. N0: No regional lymph node metastasis. M0: No distant metastasis. (from AJCC 7th Ed.) 